\title{
Effect of titanium on the primary radiation damage and swelling of vanadium-titanium alloys
}

\author{
A. O. Boev ${ }^{1, \dagger}$, K. P. Zolnikov², I. V. Nelasov ${ }^{1}$, A. G. Lipnitskii ${ }^{1}$ \\ †boev.anton.olegovich@gmail.com
}

\author{
${ }^{1}$ Belgorod State National Research University, 85 Pobeda St., Belgorod, 308015, Russia \\ ${ }^{2}$ Institute of Strength Physics and Material Science, Siberian Branch of RAS, 2/4 Akademicheskii ave., Tomsk, 634021, Russia
}

Until now, the problem of the effect of alloying elements on the development stage of atomic displacement cascades in vanadium-based alloys, which are considered as a promising group of radiation-resistant materials for thermonuclear energy, has not been investigated. In this paper, a molecular dynamic study of the atomic displacement cascade development in pure vanadium and $\mathrm{V}$-Ti alloys with titanium concentrations of 4,8 , and $16 \%$ is carried out for energies of a primary knocked-out atom of 5,10 , and $20 \mathrm{keV}$. The interactions between atoms in the V-Ti system are specified in the framework of a method developed earlier for modeling systems with metallic and covalent types of chemical bond. The interactions at small interatomic distances are taken into account for screened ions which allows one to correctly simulate atomic systems under high-energy conditions. The simulations were carried out at $700 \mathrm{~K}$ that corresponds to the lower limit of the operating temperature range of the alloys. The purpose of the work is to establish the features of the effect of titanium on the cascade characteristics and the possibility of reducing the radiation swelling by titanium doping. The main characteristics of cascades considered in this paper are the number of generated defects at different stages of a cascade and the structure of the radiation-damaged region. The distribution of surviving defects of vacancy and interstitial types is calculated in accordance with the concentration of titanium and energy of a primary knocked-out atom. It has been proved that titanium doping results in a decrease in the size of the vacancy clusters formed after cascades.

Keywords: vanadium-titanium, molecular dynamics simulation, atomic collision cascade, primary radiation damage.

УДК: 539.8

\section{Влияние титана на первичную радиационную повреждаемость и распухание сплавов ванадий-титан}

\begin{abstract}
Боев А. О. ${ }^{1 \dagger}$, Зольников К. П. ${ }^{2}$, Неласов И. В. ${ }^{1}$, Липницкий А. Г. ${ }^{1}$
${ }^{1}$ Белгородский государственный национальный исследовательский университет, ул. Победы, 85, Белгород, 308015, Россия

${ }^{2}$ Институт физики прочности и материаловедения СО РАН, пр-т Академический, 2/4, Томск, 634021, Россия

До настоящего времени остается не исследованным вопрос влияния легирующих элементов на стадию развития каскада атомных смещений в сплавах на основе ванадия, которые рассматриваются в качестве одной из перспективных групп радиационно-стойких материалов для термоядерной энергетики. В данной работе проводится молекулярно-динамическое исследование процесса развития каскадов атомных смещений в чистом ванадии и сплавах $\mathrm{V}$-Ti с концентрациями титана 4, 8 и 16\% при энергиях первично выбитого атома 5, 10 и 20 кэВ. Взаимодействия между атомами в системе V-Ti задается в рамках метода, развитого ранее для моделирования систем с металлическим и ковалентным типом химической связи. Взаимодействия на малых межатомных расстояниях учитывается в подходе экранированных ионов, что позволяет корректно моделировать атомные системы в условиях высокоэнергетического воздействия. Моделирование проводилось при температуре $700 \mathrm{~K}$, что соответствует нижнему пределу интервала рабочих температур рассматриваемых сплавов. Работа направлена на установление особенностей влияния титана на характеристики каскадов атомных смещений и возможность уменьшения радиационного распухания сплава при легировании титаном. Основными характеристиками каскадов атомных смещений, рассмотренных в данной работе, являются количество генерируемых дефектов на разных стадиях развития каскада и структура радиационноповрежденной области. Рассчитано распределение выживших дефектов вакансионного и межузельного типа по размеру в зависимости от концентрации титана и энергии первично выбитого атома. Обнаружено, что легирование титаном приводит к уменьшению размеров вакансионных кластеров, формируемых каскадами атомных смещений.
\end{abstract}

Ключевые слова: ванадий-титан, молекулярно-динамическое моделирование, каскады атомных смещений, первичная радиационная повреждаемость. 


\section{Introduction}

Alloys based on V-Ti system are known for their low value of irradiation-induced swelling, which is achieved by means of doping with titanium. Among these, the alloys with the titanium concentration of $4-5 \%$ are characterized by the minimum value of irradiation-induced swelling. This fact was established in the experiments on radiation treatment of $\mathrm{V}$-Ti alloys, where the concentration of Ti was changed from 0 to $20 \%$ [1]. The contribution of the cascade development stage to the effect has not been studied yet due to the limitations in experimental approaches to obtaining detailed atomic level information on the processes in materials. At the same time, the scale of cascades' development makes them easy to be explored by means of computer simulation methods on the atomic level.

The effect of titanium on the irradiation-induced swelling of vanadium was studied by means of computer simulation methods [2-6], however, by the moment the stage of the atomic displacement cascade development (the ballistic stage in [4]) has only been explored for pure vanadium [7]. On this stage, the kinetic energy of a high-energy particle is redistributed between lattice atoms through the elastic interaction. The number of lattice atoms displaced from their sites increases sharply and reaches its maximum. The result of the second (recombinational) stage, the time scale of which is several picoseconds, is the formation of point defects and their clusters formed by the atomic displacement cascade, which are known to be the primary material condition after radiation damage. On the third stage, the defects that "survived" the recombination process continue to evolve as a result of diffusional atomic displacements (ground state). In [7], the first stage of vanadium damage was studied by means of molecular dynamics (MD) using interatomic potentials constructed in the frames of centrally-symmetric approximation. The authors of [7] showed that the vacancies after the cascade stayed in the central part of the simulated cell and the interstitial atoms moved to the periphery.

It should be noted that alloying elements have an effect on the primary radiation damage not less than that of the internal structural features of the material [8,9] (grain boundaries, interphase boundaries, inclusions of different types, etc.). The studies in 1970s revealed that an insignificant concentration of copper (up to $0.4 \%$ ) contributed remarkably to the embrittlement of reactor steels. This occurs due to the formation of copper-enriched clusters in the steels. MD simulation was carried out in paper [10] to define the possibility of copper segregation in the process of grouping of $\mathrm{Cu}$ atoms with vacancies in the region of atomic displacement cascade development. The primary knocked-on atom (PKA) energies amounted to 5,10 and $20 \mathrm{keV}$, the temperature of simulated crystallite was $600 \mathrm{~K}$, and the concentration of copper was preset to be $0,0.2$ and 2.0 at.\%. The simulation results showed that there were no copper segregation processes in the atomic displacement cascades. It appears that copper clusters are formed within a longer period of time. The similar simulation results were obtained when exploring $\mathrm{Fe}-\mathrm{C}$ system. The high demand for ferrite and ferritemartensite steels in the atomic power industry promoted the development of interatomic interaction for Fe-Cr alloys [11].
These potentials were used to study the effect of $\mathrm{Cr}$ on the development of atomic displacement cascades. A simulation of atomic displacement cascades with energies from 0.5 to $15 \mathrm{keV}$ at $300 \mathrm{~K}$ in Fe-Cr crystallites was performed [12,13]. Unlike $\mathrm{Fe}-\mathrm{Cu}$ system, it was found out that the presence of $\mathrm{Cr}$ impurities resulted in an insignificant increase in the number of the survived radiation defects. The insignificant effect of $\mathrm{Cr}$ atoms on the ballistic stage is due to similar atomic masses of $\mathrm{Cr}$ and $\mathrm{Fe}$. It was discovered that in the simulated crystallite highly stable mixed interstitial $\mathrm{Fe}-\mathrm{Cr}$ dumbbells were formed. About $60 \%$ of interstitial dumbbells contained $\mathrm{Cr}$ atom, while the mean concentration of $\mathrm{Cr}$ amounted to $10 \%$.

$\mathrm{V}$-based alloys are of high demand in the atomic power industry owing to their low radiation activation. However, due to the absence of realistic potentials of interatomic interaction for the V-Ti system, the possible effect of Ti on the development of atomic displacement cascades and formation of primary radiation damages has not been studied yet.

Characterization of the contribution of the cascade development stage to the mechanism of reduction of radiation swelling in vanadium by means of alloying with titanium is necessary to understand the alloying principles of new radiation-resistant materials.

The present paper is aimed at an exploration of titanium effect on the formation and evolution of defects due to the development of atomic displacement cascades in $\mathrm{V}$-Ti alloys with titanium concentration of $4,8,16 \%$ on the atomic level by means of $\mathrm{MD}$ simulation using interatomic interaction potentials for $\mathrm{V}-\mathrm{Ti}[3,14]$ constructed with an account of the angular dependence of interatomic interactions. The effect of titanium concentration on the number of vacancies and interstitial atoms as well as the structure of the radiationdamaged region depending on the PKA energy within the range of $1-20 \mathrm{keV}$ are studied. These energies correspond to the estimated values of the cascade defect formation in vanadium for neutron spectra of BN-600, IVV-2M, BOR-60 and DEMO-RF reactors [15].

\section{Simulation procedures}

The simulated crystallites of body-centered cubic lattice of $\mathrm{V}$ and substitutional solid solutions $\mathrm{V}-\mathrm{Ti}$ had a cubic shape with periodic boundary conditions in directions [100], [010] and [001]. We used 128000-node samples (12 $\mathrm{nm}$ in edge length) for PKA energies $5 \mathrm{keV}$, and 432000-node samples (18 $\mathrm{nm}$ in edge length) for energies 10 and $20 \mathrm{keV}$.

The initial temperature of the simulated crystallites amounted to $700 \mathrm{~K}$, which corresponds to the lower limit of the operating temperature range for vanadium alloys when using them as a material for a first wall of fusion reactor [16]. The simulated V-Ti crystallites differed from pure vanadium crystallites by a random substitution of 4,8 , and $16 \%$ vanadium atoms by titanium ones.

Interatomic potentials, which account for angular dependences of interatomic interactions, used for the simulation of $\mathrm{V}$-Ti system were constructed earlier in the frames of an original approach [14]. To describe short-range interactions, Ziegler-Biersack-Littmark (ZBL) repulsive potential [17] was used as implemented in [14]. The potential parameters were optimized to describe the database obtained 
by means of calculations in the frames of the electronic density functional theory (DFT). The database included the data on formation enthalpies and atomic volumes for 22 model structures [18]. The potentials used predict the melting temperature and thermal expansion of vanadium as well as the interaction of titanium atoms with vacancies and interstitial atoms in the vanadium body-centered cubic lattice in good agreement with well-known experimental data and results of DFT calculations [6]. These properties of potentials are of a great importance for a correct simulation of radiation damages of titanium-alloyed vanadium, since the effects of irradiation-induced swelling significantly depend on the homologous temperature, size factor, and characteristics of point defects complexes.

To initialize the structure for MD simulations, each sample was held at $700 \mathrm{~K}$ and zero pressure using NoseHoover thermostat [19] and Berendsen barostat [20] for 20 ps (NPT ensemble). Then one of the vanadium atoms in the center of crystallite was given a velocity corresponding to a given PKA energy in a random direction. To obtain statistical data, simulations of 10 samples with random directions of the velocity vector for each PKA energy value were carried out. Then MD runs at constant pressure and temperature with a variable time step were done.

The integration step was changed depending on the maximum atomic velocity in the simulated crystallite so that PKA displacement did not exceed $0.02 \AA$ in one step. According to this condition, the minimal time step of $0.02 \mathrm{fs}$ was chosen for PKA energies 5 and $10 \mathrm{keV}$. For $20 \mathrm{keV}$ energy, the minimal time step was equal to $0.005 \mathrm{fs}$. The maximum integration step value amounted to $1 \mathrm{fs}$ for all PKA energy values.

The analysis of the evolution of damaged regions in the crystallites was done by means of visualization using WignerSeitz defect analysis modifier realized in OVITO package [21]. Point defect clusters were detected by means of cluster analysis method installed in OVITO software package.

\section{Results and discussion}

Fig. 1 presents the results of calculations of the number of Frenkel pairs during the evolution of atomic displacement cascades generated by PKA having energies of 5, 10 and $20 \mathrm{keV}$ in V, V-4Ti, V-8Ti and V-16Ti crystallites.

As it is seen in Fig. 1, the number of Frenkel pairs "survived" after the atomic displacement cascade grows with an increase of PKA energy. The addition of titanium has a little effect on this number only for $5 \mathrm{keV}$ energy. At higher PKA energies titanium in the concentrations studied does not have any influence on the formation of point defects. It should be noted that the effect of titanium manifests itself only on the ballistic stage of the cascade development. In the case of $20 \mathrm{keV}$ PKA energy 1.5 times less Frenkel pairs are formed in vanadium-titanium alloys on the ballistic stage than in pure vanadium. This is due to the formation of subcascade regions in vanadium lattice at high PKA energies, which results in an increase of the number of atoms displaced from their sites. In the case of an alloy, titanium atoms having larger ionic radius suppress the formation of subcascade regions. This is due to the fact that a higher energy is necessary to displace a titanium atom from its lattice site. Our estimations of the threshold energy necessary to displace vanadium and titanium atoms in a direction $<100>$ at $300 \mathrm{~K}$ made using the technique of [22] show that this parameter amounts to 18 and $25 \mathrm{keV}$ for vanadium and titanium, respectively.

One of the important characteristics of the cascade development region is the distribution of point radiation defects over vacancy and interstitial clusters of different sizes. Features of the size distribution of clusters largely determine
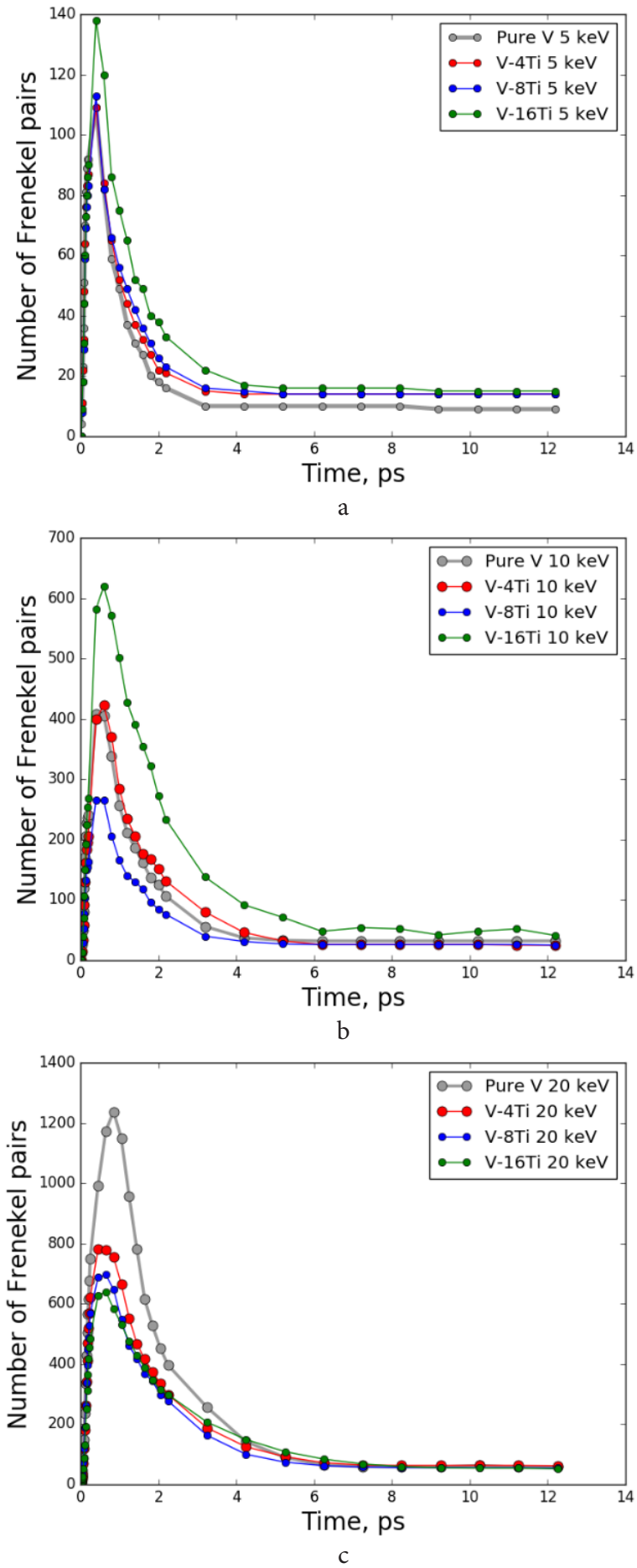

Fig. 1. The number of Frenkel pairs in pure V and V- $x \mathrm{Ti}(x=4,8,16)$ crystallites versus the simulation time for the PKA energy of 5 (a), 10 (b) and 20 (c) keV. The results were averaged over the 10 simulated samples with random orientations of the PKA velocity vector. 
the diffusion processes and have a significant effect on the following evolution of the radiation-damaged region.

Fig. 2 shows a histogram of vacancy cluster distributions (starting with divacancies) depending on their size and PKA energy for the samples under consideration with different titanium concentrations.

As one can see from the figure, the influence of titanium consists in a decreas in the sizes of vacancy clusters in a comparison with pure vanadium. Moreover, an increase of titanium concentration results in an increase in the number of monovacancies, although the total numbers of free vacancies and those binded in complexes are practically the same. This can be explained by a high binding energy between titanium and a vacancy in vanadium [6]. Titanium atoms trap the vacancies to form titanium-vacancy or titanium-vacancytitanium complexes.

As the MD simulations have shown, for all titanium concentrations considered, the interstitial atoms formed in an atomic displacement cascade region move to a periphery of the cascade region, mainly as single point defects.

Fig. 3 demonstrates the distribution of point defects in pure vanadium and V- $x$ Ti alloys $(x=4,8,16)$ at the end of the ballistic stage and on a steady stage. For visualization, crystallites where approximately the same number of Frenkel pairs $(1100 \pm 100)$ had been generated at the end of the ballistic stage were considered. This allows us to estimate the influence of the titanium concentration on the sizes of primary radiation damages in case of the same number of defects.

As is seen in Fig. 3, the damage region in V-Ti alloys is more localized as compared with pure vanadium. Moreover, with an increase of titanium concentration the size of the damaged region increases as well. On the steady stage the number of "survived" defects in all crystallites marked in Fig. 3 amounts to about 50 Frenkel pairs. At $20 \mathrm{keV}$ energy in pure vanadium subcascade regions are formed that results in a significant increase of Frenkel pairs number on the ballistic stage in comparison with the studied vanadium-titanium alloys where these regions are not formed at $20 \mathrm{keV}$ (Fig. 1c).

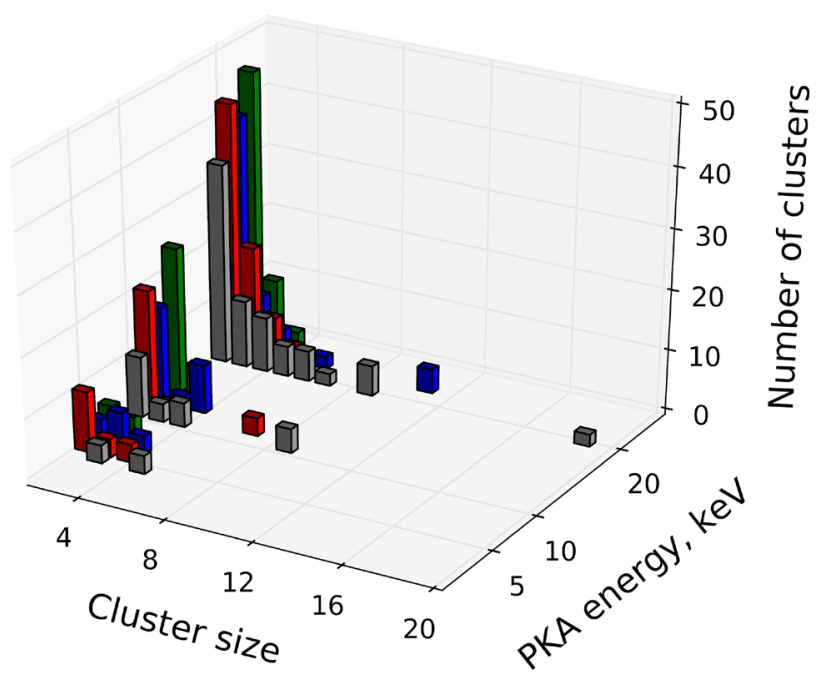

Fig. 2. (Color online) Distribution of vacancy clusters by their sizes in pure vanadium (grey color), V-4Ti (red), V-8Ti (blue), and V-16Ti (green) for PKA energies of 5, 10 and $20 \mathrm{keV}$. The total number of clusters for 10 crystallites is given for each energy of PKA.
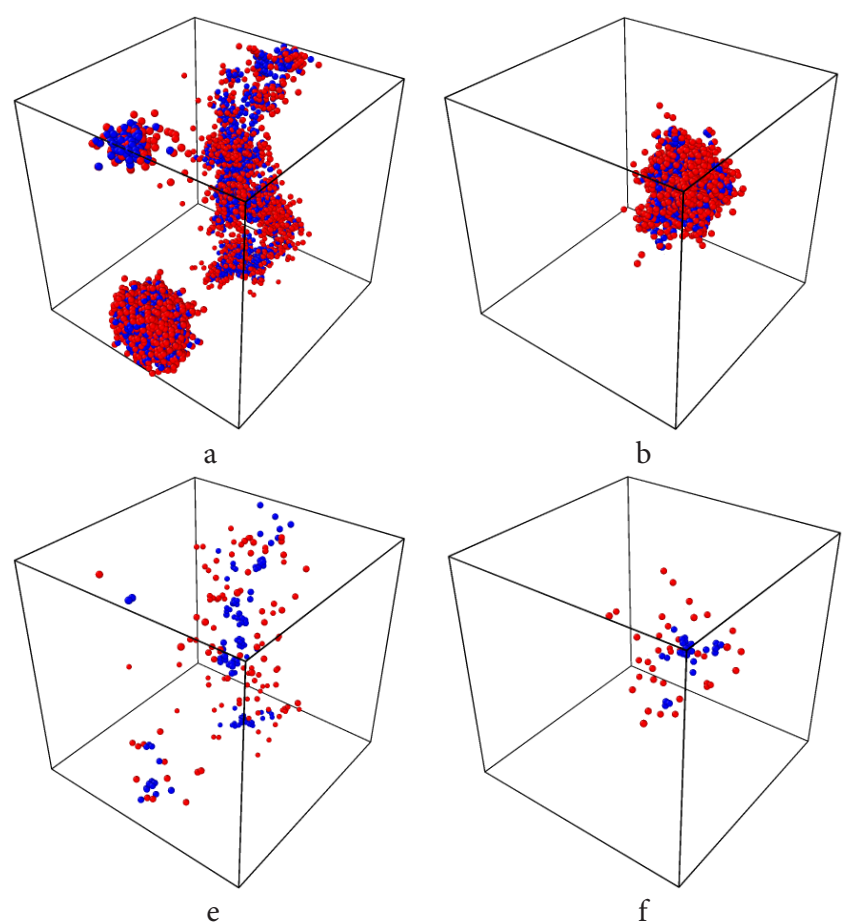
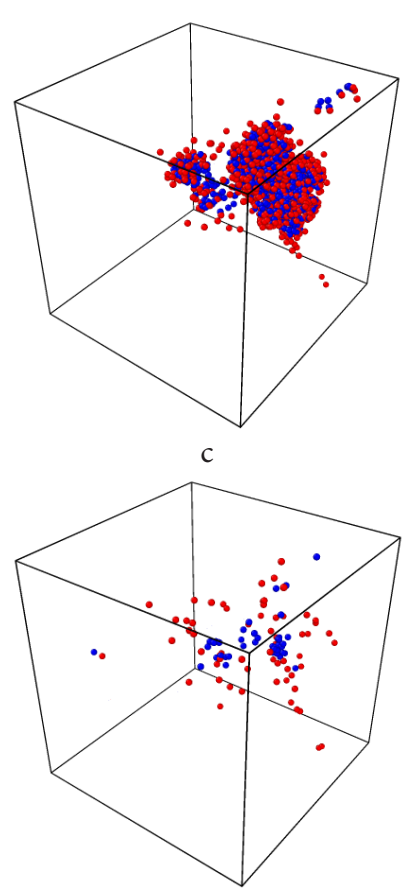

g
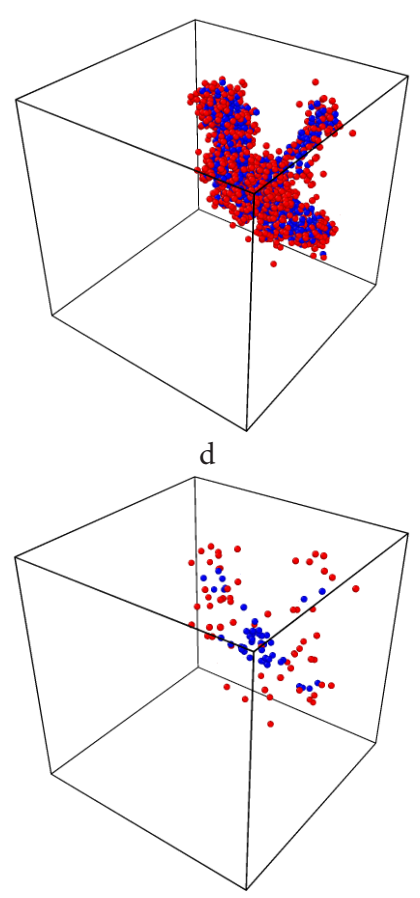

$\mathrm{h}$

Fig. 3. (Color online) Point defects in the simulated crystallite containing 432000 atoms in pure vanadium (a), in alloy V-4Ti (b), in alloy V-8Ti (c) and in alloy V-16Ti (d) at the peak time and at the time of main state in 12 ps for pure vanadium (e), alloy V-4Ti (f), alloy $\mathrm{V}-8 \mathrm{Ti}(\mathrm{g})$ and alloy $\mathrm{V}-16 \mathrm{Ti}(\mathrm{h})$. The structures for crystallites with approximately equal number of point defects on the ballistic stage are presented. Vacancies and SIAs are blue and red, respectively. PKA energy is $20 \mathrm{keV}$. 


\section{Conclusions}

To the authors' knowledge, the present paper is the first to carry out MD simulations of atomic displacement cascades in $\mathrm{V}$ - $\mathrm{Ti}$ alloys with various titanium concentrations. Alloying by titanium up to $16 \%$ does not have any effect on the number of survived point defects formed by atomic displacement cascades with 5-20 keV PKA energy. It has been found that the effect of titanium manifests itself in the structure of the radiation-damaged region. When adding titanium, the size of the damaged region decreases on the ballistic and steady stages. With the increase of titanium concentration the size of survived vacancy clusters decreases and the fraction of monovacancies increases. The formation of clusters of interstitial atoms is not significant for the titanium concentrations considered. The results of the study allows one to conclude that the effect of titanium on the changes in the size and structure of the cascade development region can contribute to the reduction of irradiationinduced swelling in vanadium through a decrease of sizes of the damaged regions and formation of vacancy clusters of smaller sizes.

Acknowledgements. The reported study was funded by RFBR (Grant No.17-308-50026 mol_nr).

\section{References}

1. B. Loomis, D. Smith, F. Garner. J. Nucl. Mater. 179, 771 (1991). DOI: 10.1016/0022-3115(91)90202-I

2. C. Zhang, P. Zhang, R. Li, J. Zhao, C. Dong. J. Nucl. Mater. 442, 370 (2013). DOI: 10.1016/j.jnucmat.2013.08.032

3. A.O. Boev, I.V. Nelasov, V.N. Maksimenko, A.G. Lipnitskii, V.N. Saveliev, A.I. Kartamyshev. Defect Diffus. Forum 375, 153 (2017). DOI: 10.4028/www.scientific.net/DDF.375.153

4. S. G Psakhie, K.P. Zolnikov, D.S. Kryzhevich, A.V. Zheleznyakov, V.M. Chernov. Crystallogr. Rep. 54, 1002 (2009). DOI: 10.1134/S1063774509060157

5. A.V. Korchuganov, K.P. Zolnikov, D.S. Kryzhevich, S. G. Psakhie. Rus. Phys. J. 60, 170 (2017). DOI: 10.1007/s11182-017-1056-0

6. A.O. Boev, D. A. Aksyonov, A.I. Kartamyshev,
V.N. Maksimenko, I. V. Nelasov, A. G. Lipnitskii. J. Nucl. Mater.492,14(2017).DOI: 10.1016/j.jnucmat.2017.04.046

7. E. Alonso, M.J. Caturla, T. D. de la Rubia, J.M. Perlado. J. Nucl. Mater. 276, 221 (2000). DOI: $10.1016 /$ S0022-3115(99)00181-6

8. A.V. Korchuganov, K.P. Zolnikov, D.S. Kryzhevich, V.M. Chernov, S. G. Psakhie. Physics of Atomic Nuclei. 79(7), 1193 (2016). DOI: 10.1134/S1063778816070073

9. S.G. Psakhie, K.P. Zolnikov, D.S. Kryzhevich, A.V. Zheleznyakov, V.M. Chernov. Physical Mesomechanics. 12(1-2), $20 \quad$ (2009). DOI: 10.1016/j.physme.2009.03.003

10. C.S. Becquart, C. Domain, J. C. van Duysen, J.M. Raulot. J. Nucl. Mater. 294, 274 (2001). DOI: 10.1016/S0022-3115(01)00421-4

11. L. Malerba, A. Caro, J. Wallenius. J. Nucl. Mater. 382, 112 (2008). DOI: 10.1016/j.jnucmat.2008.08.014

12. D. Terentyev, L. Malerba, M. Hou. Nucl. Instr. Meth. B. 228, 164 (2005). DOI: 10.1016/j.nimb.2004.10.039

13. D. Terentyev, L. Malerba. J. Nucl. Mater. 329-333, 1161 (2004). DOI: 10.1016/j.jnucmat.2004.04.269

14. A. G. Lipnitskii, V.N. Saveliev. Comput. Mater. Sci. 121, 67 (2016). DOI: 10.1016/j.commatsci.2016.04.008

15. V.T. Zabolotnyy, E.E. Starostin. Fiz. Khim. Obrab. Mater. 6, 5 (2006). (in Russian) [В.Т. Заболотный, Е. Е. Старостин. Физика и химия обработки материалов. 6, 5 (2006).]

16. A. Impagnatiello, T. Toyama, E. JimenezMelero. J. Nucl. Mater. 485, 122 (2017). DOI: 10.1016/j.jnucmat.2016.12.040

17. J. Ziegler, J. Biersack, U. Littmark. Stopp. Range Ions Solids. 1, 109 (1985).

18. A. Kartamyshev, A. Boev, et al. BSU Scient. bullet.: Math. and Phys. 121, 67 (2016).

19. W. G. Hoover. Phys. Rev. A. 31, 1695 (1985). DOI: 10.1103/PhysRevA.31.1695

20. H. J. C. Berendsen, J.P. M Postma, W. F. van Gunsteren, A. DiNola, J.R. Haak. J. Chem. Phys. 81, 3684 (1984). DOI: $10.1063 / 1.448118$

21. A. Stukowski. Modell. Simul. Mater. Sci. Eng. 18, 015012 (2009).

22. L. A. Zepeda-Ruiz, S. Han, D. J. Srolovitz, R. Car, B. D. Wirth. Phys. Rev. B. 67(13), 134114 (2003). 